\title{
Component effects on crystallization of RE-containing aluminoborosilicate glass
}

\author{
Syazwani Mohd Fadzil,,${ }^{\mathrm{a}, \mathrm{b} 1}$ Pavel Hrma, ${ }^{\mathrm{a}, \mathrm{c}}$ Michael J. Schweiger, ${ }^{\mathrm{c}}$ \& Brian J. Riley ${ }^{\mathrm{c}}$ \\ ${ }^{a}$ Division of Advanced Nuclear Engineering, Pohang University of Science and Technology, 790784 Pohang, South Korea \\ ${ }^{b}$ School of Applied Physics, Faculty of Science and Technology, The National University of Malaysia, 43650 Bandar Baru \\ Bangi, Selangor, Malaysia \\ ${ }^{c}$ Pacific Northwest National Laboratory, P.O. Box 999, Richland, Washington, United States
}

\begin{abstract}
Lanthanide-aluminoborosilicate (LABS) glass is one option for immobilizing rare earth (RE) oxide fission products generated during reprocessing of pyroprocessed fuel. This glass system can accommodate a high loading of RE oxides and has excellent chemical durability. The present study describes efforts to model equilibrium crystallinity as a function of glass composition and temperature as well as liquidus temperature $\left(T_{L}\right)$ as a function of glass composition. The experimental method for determining $T_{L}$ was ASTM C1720-11. Typically, three crystalline phases were formed in each glass: Ce-borosilicate $\left(\mathrm{Ce}_{3} \mathrm{BSi}_{2} \mathrm{O}_{10}\right)$, mullite $\left(\mathrm{Al}_{10} \mathrm{Si}_{2} \mathrm{O}_{19}\right)$, and corundum $\left(\mathrm{Al}_{2} \mathrm{O}_{3}\right)$. Cerianite $\left(\mathrm{CeO}_{2}\right)$ was a common minor crystalline phase and Nd-silicate $\left(\mathrm{Nd}_{2} \mathrm{Si}_{2} \mathrm{O}_{7}\right)$ occurred in some of the glasses. In the composition region studied, $T_{L}$ decreased as $\mathrm{SiO}_{2}$ and $\mathrm{B}_{2} \mathrm{O}_{3}$ fractions increased and strongly increased with increasing fractions of RE oxides; $\mathrm{Al}_{2} \mathrm{O}_{3}$ had a moderate effect on the $T_{L}$ but, as expected, it strongly affected the precipitation of Al-containing crystals.
\end{abstract}

Keywords: lanthanide borosilicate glass, pyroprocessing, liquidus temperature, crystalline phases

\section{Introduction}

The Korea Atomic Energy Research Institute as well as Korean Hydro and Nuclear Power are focusing research and development efforts on radioactive waste management in Korea [1]. The research covers waste treatment, disposal of high-level waste (HLW) as well as low- and intermediate-level wastes, and interim storage of spent nuclear fuel (SNF). The objectives are focused on waste treatment and volume reduction technology, low-level waste vitrification technology, lowand intermediate-level waste disposal and safety assessment technology, improvement of existing technology for SNF storage and transportation, and development of advanced SNF storage technology [1].

\footnotetext{
${ }^{1}$ Corresponding author. Tel.: +6-03-89215929; fax: +6-03-89213777. E-mail address: syazwanimf@ukm.edu.my (S. Mohd Fadzil).
} 
After the Fukushima accident (March 11, 2011), SNF management has been an issue because, currently, SNF is kept in at-reactor storage that will reach maximum capacity in 2024. In 2008, the SNF management decided to develop pyroprocessing, a reprocessing technology for SNF with minimal proliferation risk [2,3]. Instead of direct disposal of SNF, which is a low-cost option, the fuel will be recycled by a treatment that increases resource utilization.

Korea is participating in collaborative projects using pyroprocessing technology [1]. According to the United States-Republic of Korea agreement on pyroprocessing, the first stage of the Korea Advanced Pyroprocessing Facility is planned for 2021 with commercial-scale demonstration by 2025 [1]. The technology has been under development at the Korea Atomic Energy Research Institute since 1997 and was tested in a pilot-scale study in 2007. The pyroprocessing technology is used to recycle SNF to integrate useful resources and reduce the waste volume in the repository by a factor of 100 . The process includes pre-treatment, electroreduction, electrorefining, electrowinning, and waste salt treatment $[1,3]$.

Pyroprocessing is a method for separating uranium and transuranic elements in an electroreduction process to be recycled in fast reactors as fuel $[4,5]$. During this process, the rare earth (RE) fission products, now separated for waste processing, are released into the electrorefiner and converted to chlorides [4-6]. The RE chlorides can be selectively turned into a mixture of oxides and oxychlorides by oxygen sparging [7]. The RE oxide/oxychloride mixture will have to be immobilized in a stable waste form such as a glass [8-10].

In a previous study, a series of borosilicate glasses were fabricated with several RE oxides representative of RE fission products found in the electrorefiner following pyroprocessing [10]. The liquidus temperatures $\left(T_{L}\right)$ and chemical durability of these glasses were determined. In this work, lanthanide-aluminoborosilicate (LABS) glasses were chosen for their high waste loading and excellent durability. A similar glass with $\mathrm{SrO}$ included in the composition was proposed for the immobilization of americium/curium waste stored at the Savannah River Site in F-Canyon Tank 17.1 $[11,12]$.

Waste glass compositions vary widely and so do waste glass properties, including crystal types, crystal fractions, and the $T_{L}$. Depending on the melter type, both crystal fractions and the $T_{L}$ can limit the waste loading because crystal formation can change the viscosity of the melt, can result in clogging of the melter pour spout, and can pull out critical glass-forming components from the melt, thus can negatively affect chemical durability. Generally, the processing technology that allows a high fraction of crystallinity can produce durable waste forms with high waste loading. Unlike the conventional Joule-heated melters that operate at $\sim 1150^{\circ} \mathrm{C}$, an advanced melter technology such as a 
cold crucible induction melter can operate at temperatures as high as $\sim 1700^{\circ} \mathrm{C}$, thus possibly avoiding crystallization problems altogether $[22,23]$.

In this work, we designed a matrix of LABS glasses and experimentally determined their equilibrium crystal fractions as functions of temperature. Typically, test matrices to explore the glass composition regions include varying one chemical component at a time, replacing one component with another, and using a statistical design to vary several components at a time [20,21]. The experimental approach in this work is centered on the one-at-a-time variation of each component. Though this approach does not provide information about interactive effects of the components, it represents the simplest design for obtaining component effects over a large composition region and allows for helpful graphical visualization of experimental data. To relate equilibrium crystal fractions and the $T_{L}$ to glass composition, we fitted to data an empirical model that is based on chemical thermodynamics. Various models for crystallinity as a function of glass composition and temperature, and $T_{L}$ as a function of glass composition have been used for HLW glasses with various primary crystalline phases [12-21].

\section{Methodology}

Experimental steps for this study consisted of glass fabrication followed by heat treatment of glass samples to determine $T_{L}$ by the crystal fraction extrapolation method. More details of the process are found in the ASTM procedure described elsewhere [24]. Analytical techniques used were optical microscopy, scanning electron microscopy, energy dispersive spectroscopy, and X-ray diffraction.

\subsection{Glass fabrication}

The 250-g batches of lanthanide-aluminoborosilicate (LABS) glasses (Table 1) were made from fine powders consisting of oxides (i.e., $\mathrm{SiO}_{2}, \mathrm{Al}_{2} \mathrm{O}_{3}, \mathrm{CeO}_{2}$, and $\mathrm{Nd}_{2} \mathrm{O}_{3}$ ) and boric acid. The batches were mixed and homogenized in an agate vibratory mill for several minutes. Batches were melted at 1325 to $1475^{\circ} \mathrm{C}$ for $1 \mathrm{~h}$ in a Pt/10\% Rh crucible covered tightly with a Pt lid. The melting temperatures $\left(T_{\mathrm{m}}\right)$ used in this study were determined by visual observations where a temperature of $1325^{\circ} \mathrm{C}$ was used and if the glass had not melted after a few minutes, the temperature was increased iteratively until the melt appeared.

The melts were poured on an Inconel ${ }^{\circledR}$ plate to air quench. The cooled glasses were ground in a tungsten carbide mill for several minutes, remelted for $1 \mathrm{~h}$, and then quenched under the same conditions. Glass melting temperatures were selected within the range of 1300 to $1500^{\circ} \mathrm{C}$ to facilitate processing in a cold crucible induction melter. Glasses were observed with an optical microscope to determine if phase separation or crystallization occurred to verify that all glasses were free of crystals prior to testing. No attempt was made to measure the glass compositions after melting because the 
glasses were batched using analytical grade chemicals and melted in covered crucibles. No volatility of glass components was observed during melting.

Table 1 summarizes the glass compositions organized into five series by varied compositions. The baseline glass, L-53, was selected for high waste loading (53 mass\%). Altogether, 21 homogeneous glasses were produced including baseline glass (L-53) by adding or removing 3 and 5 mass\% of each component one at a time. The "H" and "L" letters in the glass identifications denote "high" and "low," representing an increase or decrease of a component fraction from baseline composition, respectively, while "S," "B," "A," "C," and "N" letters denote the $\mathrm{SiO}_{2}, \mathrm{~B}_{2} \mathrm{O}_{3}, \mathrm{Al}_{2} \mathrm{O}_{3}, \mathrm{CeO}_{2}$, and $\mathrm{Nd}_{2} \mathrm{O}_{3}$ oxide component, respectively. The numbers " 3 " and " 5 " at the end of each glass nomenclature denote the amount of each component changed from the baseline in mass $\%$. The melting temperature was varied based on glass composition. The $T_{m}$ values and waste (RE) loadings (in mass $\%$ ) are included in Table 1 , and component composition ranges are listed in Table 2.

\subsection{Equilibrium crystal fractions, liquidus temperature, and phase analysis}

Liquidus temperature was measured following ASTM C1720-11, specifically the crystal fraction extrapolation method [24]. Glass samples were heat-treated for $24 \pm 2 \mathrm{hrs}$ at temperatures between $900^{\circ} \mathrm{C}$ and $1200^{\circ} \mathrm{C}$. Selected samples were heat treated in duplicate at different times for reproducibility (the results were included as separate data points). After each heat treatment, the samples were air quenched and a portion was crushed in a tungsten carbide mill to a fine powder with a known amount of $\mathrm{CaF}_{2}$ as an internal standard. The powdered samples were analyzed with a Bruker $^{\circledR}$ D8 Advance (Bruker AXS Inc., Madison, WI) X-ray diffractometer so that the crystalline phases could be identified using the DIFFRAC ${ }^{\text {plus }}$ EVA (Bruker AXS) and quantified with wholepattern fitting using TOPAS 4.2 (Bruker AXS) software. The uncertainty of temperature was around $\pm 3^{\circ} \mathrm{C}$ while the crystal fraction extrapolation method has around \pm 0.5 mass $\%$ error.

\subsection{Models}

The equilibrium crystal fraction is generally not a linear function of temperature even for ideal binary mixtures for which

$$
c=c_{\max }\left\{1-\exp \left[-B_{L}\left(\frac{1}{T}-\frac{1}{T_{L}}\right)\right]\right\}
$$

where $c$ is the equilibrium crystal fraction, and $c_{\max }, B_{L}$, and $T_{L}$ are coefficients that are independent of temperature, but are functions of composition. 
Commonly, several crystalline phases coexist in a glass at equilibrium. If Equation (1) can fit $c$ versus $T$ data for more than one crystalline phase, we need to use a subscript for each phase:

$$
c_{j}=c_{\max , j}\left\{1-\exp \left[-B_{L j}\left(\frac{1}{T}-\frac{1}{T_{L j}}\right)\right]\right\}
$$

where the subscript $j$ stands for the $j$-th crystalline phase and $c_{j}$ is the $j$-th crystalline phase mass fraction. Here, $T_{L j}$, is the $j$-th crystalline phase "liquidus temperature," where the quotes apply when the $j$-th crystalline phase is not the primary phase.

For a reasonably small composition region, such as that listed in Table 2, we can model $T_{L j}$ as linear function of composition using the relationship [12-21]:

$$
T_{L j}=\sum_{i-1}^{N} T_{L i j} g_{i}
$$

where $T_{L i j}$ is the $i$-th component coefficient for the $j$-th crystalline phase, $N$ is the number of components in the model, and $g_{i}$ is the mass fraction of the $i$-th component in glass.

Similarly, we can write for $B_{L j}$ and $\mathrm{c}_{\max , j}$ :

$$
B_{L j}=\sum_{i-1}^{N} B_{L i j} g_{i}
$$

and

$$
c_{\max , j}=\sum_{i-1}^{N} c_{\max , i j} g_{i}
$$

Note that if the component coefficient value, such as $T_{L i j}, B_{L i j}$, or $\mathrm{c}_{\max , i j}$, is lower than the minimum value of the associated property of glasses in the experimental dataset, such as $T_{L j}, B_{L j}$, or $\mathrm{c}_{\max , j}$, an increase of the content of the $i$-th component decreases the value of this property in all glasses within the experimental composition region. If the component coefficient value is higher than the maximum value of the associated property, an increase of the content of the $i$-th component tends to increase the property value over the experimental composition region. Finally, if the component coefficient value lies between the minimum and maximum for the property values, the $i$-th component has little effect on the property [18].

\section{Results and Discussion}


In this study, nearly 140 crystallinity data points were generated within the temperature range of $950^{\circ} \mathrm{C}$ to $1200^{\circ} \mathrm{C}$. The crystalline phases observed were Ce-borosilicate $\left(\mathrm{Ce}_{3} \mathrm{BSi}_{2} \mathrm{O}_{10}\right)$, mullite $\left(\mathrm{Al}_{10} \mathrm{Si}_{2} \mathrm{O}_{19}\right)$, corundum $\left(\mathrm{Al}_{2} \mathrm{O}_{3}\right)$, and cerianite $\left(\mathrm{CeO}_{2}\right)$. Stillwellite-Ce and Nd-silicate $\left(\mathrm{Nd}_{2} \mathrm{Si}_{2} \mathrm{O}_{7}\right)$ were only detected in a few samples. Fig. 1 depicts the micrograph of the L-53 glass heat-treated at $999^{\circ} \mathrm{C}$ for $23.8 \mathrm{~h}$; the crystalline phases formed a dense network within the bulk glass. Crystal fractions for Ce-borosilicate, Al-containing crystalline phases (the sum of mullite plus corundum and corundum separately), and cerianite are plotted versus the heat-treatment temperature in Fig. 2 for the L-53 glass. Fig. 3 shows crystal fractions versus temperature for all other glasses. The Ce-borosilicate phase was present in 116 samples. Fractions of Al-containing crystalline phases consist of 102 data points for $\mathrm{Al}_{10} \mathrm{Si}_{2} \mathrm{O}_{19}$ and 52 data points for $\mathrm{Al}_{2} \mathrm{O}_{3}$. The sum of $\mathrm{Al}_{10} \mathrm{Si}_{2} \mathrm{O}_{19}$ and $\mathrm{Al}_{2} \mathrm{O}_{3}$ fractions presents a significant trend in all data series. Corundum barely formed in high-viscosity glasses, such as HS5, HS3, and LA5.

Table 3 summarizes the values of $c_{\max }, B_{L}$, and $T_{L}$ for Ce-borosilicate and Al-containing crystalline phases for the glasses listed in Table 1. These values were obtained by fitting Equations (2) to (5) to data. The resulting component coefficients are listed in Table 4. The correlations coefficients were $R^{2}=0.941$ for the Ce-borosilicate phase and $R^{2}=0.922$ for the Al-containing phases. The root mean square errors were $s=0.850$ and 0.437, respectively. The lines in Figs. 2 and 3 represent the model, i.e., Equations (2) to (5) with coefficients listed in Table 4.

As Figs. 2 and 3 indicate, several outlying data for the Ce-borosilicate crystals were not used for model fitting. Three outlying data points (glasses HS5, HB5, and LN5) were crystal fractions obtained at temperatures close to $T_{L}$, where the sparse crystallinity could be missed by the tiny XRD sample. One outlier (glass HS3) occurred at a low temperature at which the heat-treatment time probably did not allow the sample to reach equilibrium. Finally, the more Ce-borosilicate crystals were produced in HB3 than the model would predict. This composition is located between L-53 and HB5 compositions. The discrepancy between HS3 and the neighboring compositions, L-53 and HB5, was probably caused by an error that we were unable to trace. However, misbatching is unlikely considering good agreement between models and data for Al-containing phases in HS3.

As the coefficients listed in Table 4 indicate, adding $\mathrm{SiO}_{2}$ and $\mathrm{B}_{2} \mathrm{O}_{3}$ to glass has a tendency to decrease $T_{L}$ for the Ce-borosilicate crystals, whereas an increased $\mathrm{Al}_{2} \mathrm{O}_{3}$ content has a moderate tendency to increase $T_{L}$, and $\mathrm{CeO}_{2}$ and $\mathrm{Nd}_{2} \mathrm{O}_{3}$ have a strong tendency to increase $T_{L}$. As expected, $T_{L}$ of Al-containing crystalline phases strongly increased as the $\mathrm{Al}_{2} \mathrm{O}_{3}$ content increased, to a lesser extent as $\mathrm{CeO}_{2}$ and $\mathrm{Nd}_{2} \mathrm{O}_{3}$ were added to the glass, and decreased as $\mathrm{SiO}_{2}$ and $\mathrm{B}_{2} \mathrm{O}_{3}$ fractions increased. 
As Fig. 3 plots indicate, Al-containing crystals were typically present above the "liquidus" temperature of the Ce-borosilicate crystalline phase. However, as the temperature decreased below $T_{L}$, the Ce-borosilicate crystalline phase became dominant even for high-alumina compositions.

In the LB5 glass, a crystalline phase identified as $\mathrm{Nd}_{2} \mathrm{Si}_{2} \mathrm{O}_{7}$ occurred at $T>1100^{\circ} \mathrm{C}$. The fraction of this phase increased as temperature increased while the total Al crystal fraction sharply decreased.

Although the nonlinear model, Equation (2), was applicable to major crystalline phases, the $\mathrm{CeO}_{2}$ phase was an exception. Its content was virtually independent of temperature, indicating that $\mathrm{CeO}_{2}$ crystals might form during cooling. Table 5 lists the component coefficients of the function $c_{\mathrm{CeO}_{2}}=\sum_{i-1}^{N} c_{i \mathrm{CeO}_{2}} g_{i}$. The coefficients are based on 136 data points. After omitting five outliers, the amount of observed $\mathrm{CeO}_{2}$ ranged from 0.50 to 3.66 mass $\% ; R^{2}=0.77$ and $s=0.33$. As the coefficient values indicate, $\mathrm{CeO}_{2}$ crystal fraction decreased with increasing $\mathrm{SiO}_{2}$ and $\mathrm{B}_{2} \mathrm{O}_{3}$ content in glass, and, as expected, increased with increasing $\mathrm{CeO}_{2}$ content, whereas $\mathrm{Al}_{2} \mathrm{O}_{3}$ and $\mathrm{Nd}_{2} \mathrm{O}_{3}$ content had only moderate effects.

Fig. 4 compares the estimated Ce-borosilicate and Al-containing crystals fractions based on Equation 2 with the measured ones. The model used to estimate $\mathrm{CeO}_{2}$ crystal fraction, shown in the previous paragraph, is also included in Fig. 4. The equality lines represent and the correlation coefficient are displayed for each crystalline phase (outliers were not considered).

Our results compare favorably with literature data for LABS glasses. With the Ce-borosilicate primary phase, the $T_{L}$ values ranged from 1118 to $1248^{\circ} \mathrm{C}$ and for Al-containing crystalline phases, the $T_{L}$ values ranged from 1138 to $1303^{\circ} \mathrm{C}$. In most LABS-Sr glasses $[11,12]$, the rare earth borosilicate $\left(\mathrm{RE}_{3} \mathrm{BSi}_{2} \mathrm{O}_{10}\right)$ crystalline phase was a clearly-recognizable primary crystalline phase, but $\mathrm{Al}_{2} \mathrm{O}_{3}$ and $\mathrm{Al}_{6} \mathrm{Si}_{2} \mathrm{O}_{13}$ crystals appeared as the primary phases in a few glasses. The $T_{L}$ values were between 1153 and $1405^{\circ} \mathrm{C}$ with either $\mathrm{RE}_{3} \mathrm{BSi}_{2} \mathrm{O}_{10}, \mathrm{Al}_{2} \mathrm{O}_{3}$, or $\mathrm{Al}_{6} \mathrm{Si}_{2} \mathrm{O}_{13}$ as the primary phases [11,12]. Gasnier et al. [25] observed that the Ce-borosilicate phase was the primary crystalline phase even in Al-rich compositions. However in this study, the $\mathrm{Nd}^{3+}$ ion probably substituted for $\mathrm{Ce}^{3+}$ in the crystal structure of Ce-borosilicate phase because of similar ionic radii (98.3 and $101 \mathrm{pm}$, respectively) [26].

In HLW glasses, the primary crystalline phases are spinel and zirconium-containing minerals [1221]. Interestingly, the relationship between $c$ and $T$ experimentally observed in HLW glasses, mostly for spinel crystals, was linear [13]. In this case, $c$ can be approximated by a linear function, $c=b\left(T_{L}-\right.$ $T$ ), where $b$ is a constant coefficient. Values of the $T_{L}$ estimated by linear extrapolation of the $c$ versus $T$ relationship over a temperature interval not far below the $T_{L}$ are typically larger than carefully measured values, e.g., using multiple measurements in which the heat treatment is repeated until the 
temperature comes as close to the $T_{L}$ as possible [13] (the less laborious gradient temperature furnace method is subjected to a large uncertainty caused by the melt flow driven by surface tension gradients [27]). Thus, linear approximation of $c$ versus $T$ data is conservative for the case where crystals are not allowed to form. For any melters that tolerate crystals, the model can correctly represent $c$ as a function of $T$ and glass composition within the $T$ interval appropriate for the melter performance [23] - an advanced melter technology can tolerate crystallinity at high temperature. Findings by Bräuchle and Huppertz [28] show that $\operatorname{Pr}_{3} \mathrm{BSi}_{2} \mathrm{O}_{10}$ crystals, with a calculated density of $5.31 \mathrm{~g} \mathrm{~cm}^{-3}$, is an analog to the Ce-borosilicate crystal $\left(\mathrm{Ce}_{3} \mathrm{BSi}_{2} \mathrm{O}_{10}\right)$. If the Ce-borosilicate crystal has a similar density to $\operatorname{Pr}_{3} \mathrm{BSi}_{2} \mathrm{O}_{10}$, the crystal can potentially settle to form a sludge on the bottom of the melter. It has been shown that spinel with density of $5.2 \mathrm{~g} \mathrm{~cm}^{-3}$ can settle in the bottom of a conventional Joule-heated melter and this will decrease the melter lifetime [14]. This consequence is lessened if the crystallite sizes are small and because the settling rates are reduced and more of the crystals are discharged with the melt. Even though a nonlinear model, such as that of Equation (1), fits the data points better, the linear model could be preferable because it is easier for mathematical optimization. However, as Section 3 demonstrates, measured $c$ versus $T$ data for crystals in LABS compositions can be best fitted with the nonlinear model, Equation (1).

\section{Conclusion}

The LABS glass has good chemical durability and is a feasible option to immobilize RE oxide fission products from reprocessing of pyroprocessed used nuclear fuel. Also, this glass has a high waste loading capacity of $>50$ mass $\%$. This work was conducted to find the effect of glass components on $T_{L}$ by varying the chosen baseline glass composition one component at a time. The LABS glasses precipitated $\mathrm{Ce}_{3} \mathrm{BSi}_{2} \mathrm{O}_{10}$ as the major phase, conjointly with $\mathrm{Al}_{10} \mathrm{Si}_{2} \mathrm{O}_{19}$ and $\mathrm{CeO}_{2}$. Some of the glasses precipitated $\mathrm{Al}_{2} \mathrm{O}_{3}$, which affected the crystal fraction of $\mathrm{Al}_{10} \mathrm{Si}_{2} \mathrm{O}_{19}$ in heat-treated samples. A few glasses contained $\mathrm{CeBSiO}_{5}$ while one sample contained $\mathrm{Nd}_{2} \mathrm{Si}_{2} \mathrm{O}_{7}$. This study may help with continued experimental efforts that would help Korean agencies to see value in using this waste form as it has high waste loading and can be of exceptional economic value.

A nonlinear model was fit to the dataset to obtain fractions of Ce-borosilicate and Al-containing crystalline phases as functions of temperature and glass composition in mass fractions of oxides. Generally, the $T_{L}$ increased as $\mathrm{SiO}_{2}$ and $\mathrm{B}_{2} \mathrm{O}_{3}$ fractions decreased and as the $\mathrm{CeO}_{2}, \mathrm{Nd}_{2} \mathrm{O}_{3}$, and $\mathrm{Al}_{2} \mathrm{O}_{3}$ fractions increased. These components had a similar effect on the crystallization of $\mathrm{CeO}_{2}$, which, however, was not affected by temperature and is suspected to precipitate during glass quenching. The model treats the coexisting major crystalline phases individually (except Al-containing phases, for 
which fractions were summed), ignoring their interactions through their effects on matrix glass composition.

\section{Acknowledgement}

The authors greatly appreciate B.R. Johnson and other staff members of Pacific Northwest National Laboratory (PNNL) with the financial support of the Department of Energy's Waste Treatment and Immobilization Plant Federal Project Office under the direction of A.A. Kruger. PNNL is operated by Battelle for the U.S. Department of Energy under Contract Number DE-AC0576RL01830. This work was also supported by the BK21+ program through the National Research Foundation of Korea funded by the Ministry of Education, Science and Technology.

\section{References}

[1] J.-I. Yun, Y.H. Jeong, J.H. Kim, Republic of Korea: experience of radioactive waste (RAW) management and contaminated site clean-up. In Lee, W.E., Ojovan, M.I., Jantzen, C.M. (Eds.), Radioactive Waste Management and Contaminated Site Clean-Up” Processes, technologies and international experience. UK: Woodhead Publishing Limited, 2013, pp. 673-695.

[2] M.J. Song, J. Nuc. Fuel Cycle \& Waste Tech. 1 (1) (2013) 1-7.

[3] H. Lee, J.-M. Hur, J.-G. Kim, D.-H. Ahn, Y.-Z. Cho, S.-W. Paek, Energy Procedia 7 (2011) 391395.

[4] H. Lee, G.-I. Park, K.-H. Kang, J.-M. Hur, J.-G. Kim, D.-H. Ahn, Y.-Z. Cho, E.H. Kim, Nucl. Eng. Technol. 43 (2011) 317-328.

[5] J.-H. Yoo, C.-S. Seo, E.-H. Kim, H.-S. Lee, Nucl. Eng. Technol. 40 (2008) 581-592.

[6] H.-S. Park, I.-H.Cho, H.C. Eun, I.-T. Kim, Y.Z. Cho, H.-S. Lee, Environ. Sci. Technol. 45 (2011) 1932-1939.

[7] Y.-Z. Cho, H.-C.Yang, G.-H. Park, H.-S. Lee, I.-T. Kim, J. Nucl. Mater. 384 (3) (2009) 256-261.

[8] C.W. Kim, B.G. Lee, J. Korean Radioact. Waste Soc. 11 (2013) 1-9.

[9] J.-H. Choi, I.-H. Cho, H.-C. Eun, H.-S. Park, Y.-Z. Cho, K.-R. Lee, G.I. Park, S.-H. Kim, C.-H. Shin, J.-K. Kim, J. Radioanal. Nucl. Chem. 299 (2014) 1731-1738.

[10] S. Mohd Fadzil, P. Hrma, M.J. Schweiger, B.J. Riley, J. Nucl. Mater. 465 (2015) 657-663. 
[11] D. Peeler, T.B. Edwards, I.A. Reamer, J.D. Vienna, D.E. Smith, M.J. Schweiger, B.J. Riley, J.V. Crum, Composition/property relationships for the Phase $1 \mathrm{Am} / \mathrm{Cm}$ glass variability study. WSRC-TR-99-00055, Rev. 0, Westinghouse Savannah River Company, Savannah River Site, Aiken, SC, 1999.

[12] B.J. Riley, J.D. Vienna, M.J. Schweiger, D.K. Peeler and I.A. Reamer, 1999, Liquidus temperature of rare earth-aluminoborosilicate glasses for treatment of americium and curium. In Proceedings of the Scientific Basis for Nuclear Waste Management XXIII, 608, pp 677-682, Materials Research Society, Warrendale, PA.

[13] P. Hrma, B.J. Riley, J.V. Crum, J. Matyas, J. Non-Cryst. Solids 384 (2014) 32-40.

[14] B.K. Wilson, T.J. Plaisted, J. Alton, P. Hrma, J. Mater. Sci. 37 (2002) 5327-5331.

[15] J.D. Vienna, P. Hrma, J.V. Crum, M. Mika, J. Non-Cryst. Solids 292 (2001) 1-24.

[16] P. Hrma, 1999. Modeling of Spinel Settling in Waste Glass Melter. In: Science to Support DOE Site Cleanup, PNNL-12208, UC-2000, Pacific Northwest National Laboratory, Richland, WA.

[17] P. Hrma, J.D. Vienna, M. Mika, J.V. Crum, G.F. Piepel, 1999. Liquidus Temperature Data for DWPF Glass. PNNL-11790, Pacific Northwest National Laboratory, Richland, WA.

[18] Q. Rao, G.F.Piepel, P. Hrma, J.V. Crum, J. Non-Cryst. Solids 220 (1997) 17-29.

[19] J.D. Vienna, D.K. Peeler, R.L. Plaisted, T.J. Plaisted, I.A. Reamer, R.D. Tillotson, J.V. Crum, C.A. Musick, T.L. James, 1999. Glass Formulation for Idaho National Engineering and Environmental Laboratory Zirconia Calcine High-Activity Waste, PNNL-12202, Pacific Northwest National Laboratory, Richland, WA.

[20] P. Hrma, G.F. Piepel, J.D. Vienna, S.K. Cooley, D.S. Kim, R.L. Russell, 2001. Database and Interim Glass Property Models for Hanford HLW Glasses. PNNL-13573 Pacific Northwest National Laboratory, Richland, WA.

[21] J. Vienna, D. Kim, P. Hrma, 2002. Database and Interim Glass Property Models for Hanford HLW and LAW Glasses. PNNL-14060 Pacific Northwest National Laboratory, Richland, WA.

[22] M.E. Smith, A.B. Barnes, A.S. Choi, J.C. Marra, NETEC cold crucible induction melter demonstration for SRNL with simulated Sludge Batch 4 DWPF waste, in: A. Cozzi, T. Ohji (Eds.), Environmental Issues and Waste Management Technologies in the Materials and Nuclear Industries XII, John Wiley \& Sons, Inc, New Jersey, 2009, pp. 29-37. 
[23] S. Mohd Fadzil, P. Hrma, 2016, Understanding the effect of glass composition containing RE oxide waste glass on liquidus temperature. In Proceedings of the Scientific Basis for Nuclear Waste Management XXXIX, Materials Research Society, Warrendale, PA (to be published).

[24] ASTM C1720-11, Standard Test Method for Determining Liquidus Temperature of Immobilized Waste Glasses and Simulated Waste Glasses, ASTM Int., West Conshohocken, PA, 2011.

[25] E. Gasnier, I. Bardez-Giboire, V. Montouillout, N. Pellerin, M. Allix, N. Massoni, S. Ory, M. Cabie, S. Poissonnet, D. Massiot, J. Non-Cryst. Solids 405 (2014) 55-62.

[26] R.D. Shannon, Acta Cryst. A32 (1976) 751-767.

[27] P. Hrma, D.E. Smith, J. Matyáš, J.D. Yeager, J.V. Jones, E.N. Boulos, European J. Glass Sci. Technol, Part B: Phys. Chem. Glasses 47 (2006) 64-76.

[28] S. Bräuchle, H. Huppertz, Z. Naturforsch 70(12)b (2015) 929-934. 
Figures and Tables

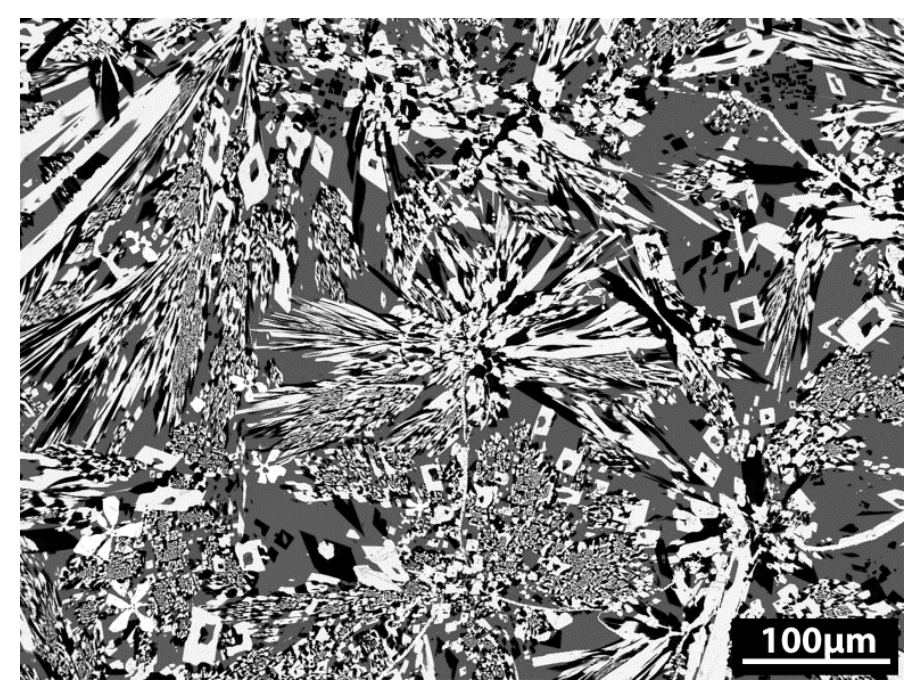

Fig. 1. SEM micrograph of L-53 heat-treated at $999^{\circ} \mathrm{C}$ for $23.8 \mathrm{~h}$.

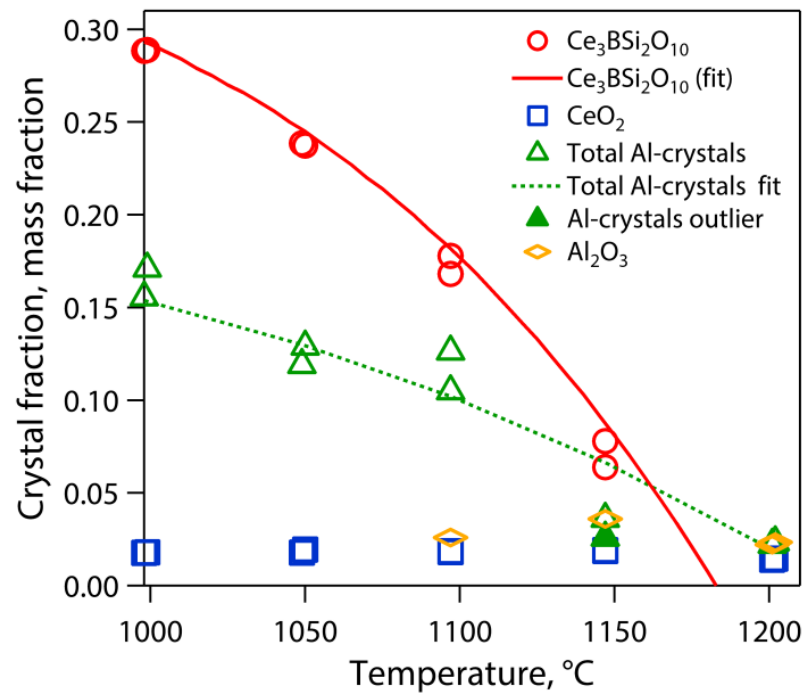

Fig. 2. Crystal mass fractions as a function of temperature for the baseline glass, L-53 (in duplicate). 


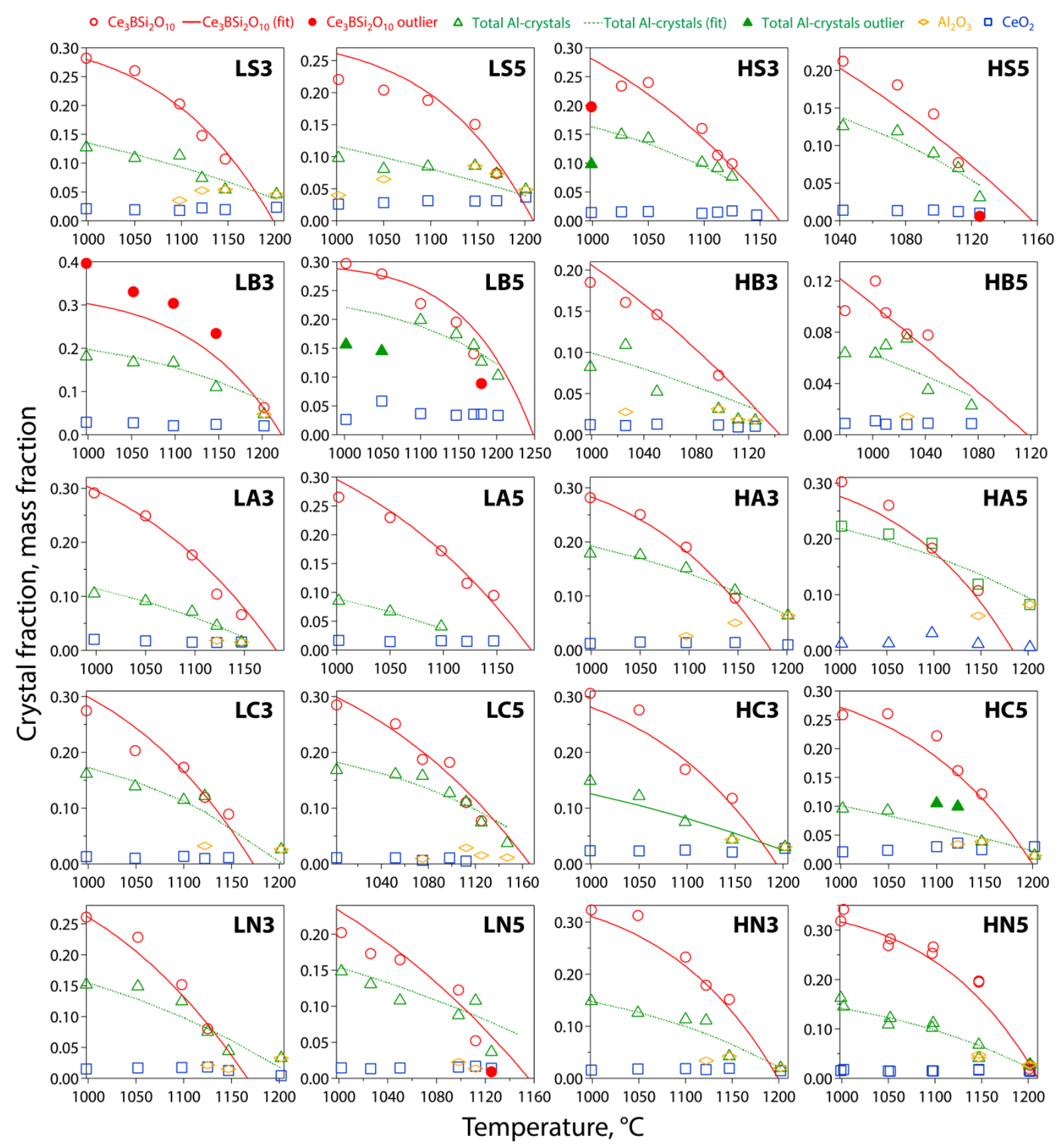

Fig. 3. Crystal mass fractions as a function of temperature for the various series of glasses. The legend for all of the plots is shown at the top. 


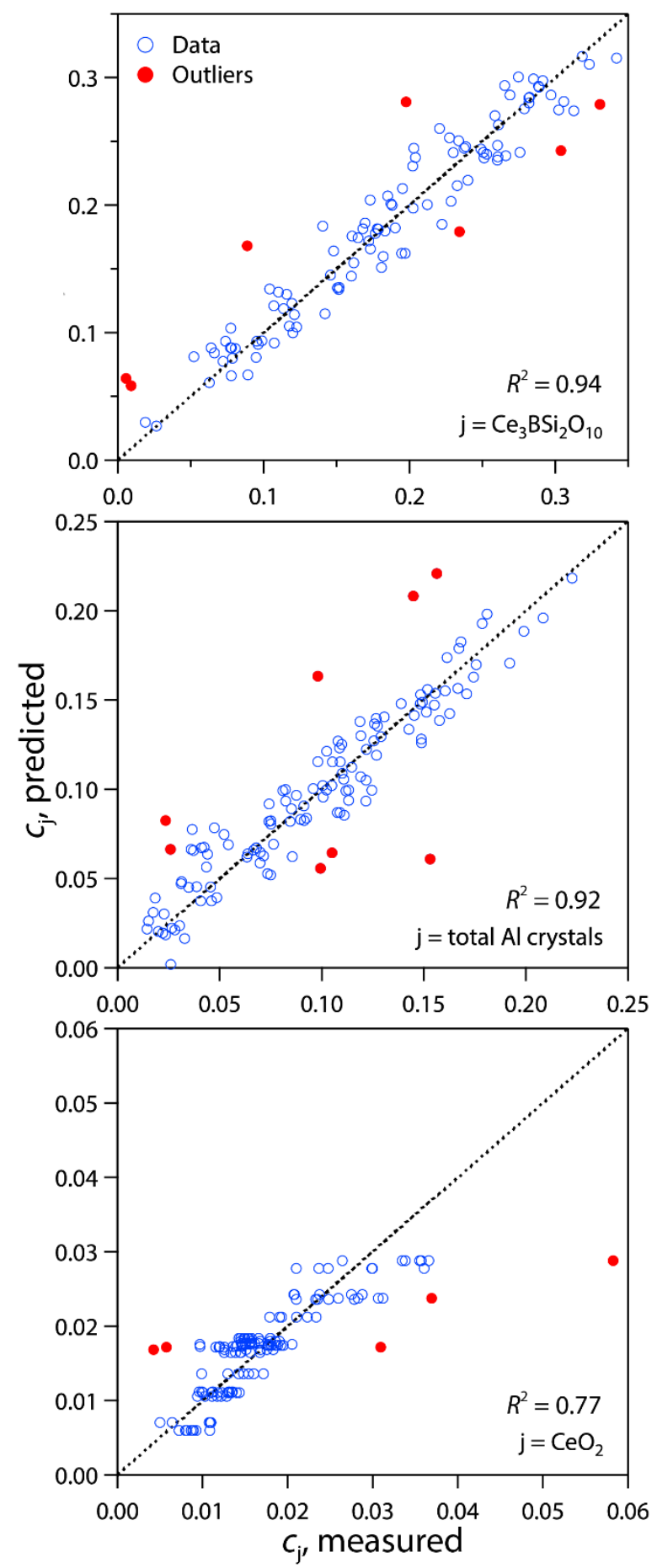

Fig. 4. Measured and predicted $\mathrm{c}_{j}$ where $j \equiv \mathrm{Ce}_{3} \mathrm{BSi}_{2} \mathrm{O}_{10}$ and total $\mathrm{Al}$ crystals (fitted by Equation 2), or $j=\mathrm{CeO}_{2}$ (fitted by $c_{\mathrm{CeO}_{2}}=\sum_{i-1}^{N} c_{i \mathrm{CeO}_{2}} g_{i}$ ). Correlation coefficients for the equality line are included on the plots, together with outliers. 
Table 1. LABS glass compositions in mass fractions, melting temperature $\left(T_{m}\right)$, and waste loading (in mass\%).

\begin{tabular}{|c|c|c|c|c|c|c|c|c|}
\hline \multicolumn{2}{|c|}{ Glass } & \multirow{2}{*}{$\frac{\mathbf{S i O}_{\mathbf{2}}}{0.1973}$} & \multirow{2}{*}{$\begin{array}{c}\mathbf{B}_{\mathbf{2}} \mathbf{O}_{\mathbf{3}} \\
0.0797\end{array}$} & \multirow{2}{*}{$\begin{array}{l}\mathbf{A l}_{\mathbf{2}} \mathbf{O}_{\mathbf{3}} \\
0.1930\end{array}$} & \multirow{2}{*}{$\begin{array}{c}\mathbf{C e O}_{2} \\
0.2024\end{array}$} & \multirow{2}{*}{$\begin{array}{l}\mathbf{N d}_{\mathbf{2}} \mathbf{O}_{\mathbf{3}} \\
0.3276\end{array}$} & \multirow{2}{*}{$\frac{\boldsymbol{T}_{\boldsymbol{m}}\left({ }^{\circ} \mathbf{C}\right)}{1325}$} & \multirow{2}{*}{$\begin{array}{c}\begin{array}{c}\text { Waste } \\
\text { loading }\end{array} \\
53.0\end{array}$} \\
\hline Baseline & L-53 & & & & & & & \\
\hline \multirow{4}{*}{$\begin{array}{l}\mathrm{SiO}_{2} \\
\text { series }\end{array}$} & HS5 & 0.2473 & 0.0747 & 0.1810 & 0.1898 & 0.3072 & 1325 & 49.7 \\
\hline & HS3 & 0.2273 & 0.0767 & 0.1858 & 0.1949 & 0.3153 & 1325 & 51.0 \\
\hline & LS3 & 0.1673 & 0.0826 & 0.2002 & 0.2100 & 0.3398 & 1325 & 55.0 \\
\hline & LS5 & 0.1473 & 0.0846 & 0.2051 & 0.2150 & 0.3480 & 1350 & 56.3 \\
\hline \multirow{4}{*}{$\begin{array}{l}\mathrm{B}_{2} \mathrm{O}_{3} \\
\text { series }\end{array}$} & HB5 & 0.1866 & 0.1297 & 0.1825 & 0.1914 & 0.3098 & 1350 & 50.1 \\
\hline & HB3 & 0.1909 & 0.1097 & 0.1867 & 0.1958 & 0.3169 & 1350 & 51.3 \\
\hline & LB3 & 0.2037 & 0.0497 & 0.1993 & 0.2090 & 0.3382 & 1365 & 54.7 \\
\hline & LB5 & 0.2080 & 0.0297 & 0.2035 & 0.2134 & 0.3453 & 1385 & 55.9 \\
\hline \multirow{4}{*}{$\begin{array}{l}\mathrm{Al}_{2} \mathrm{O}_{3} \\
\text { series }\end{array}$} & HA5 & 0.1851 & 0.0747 & 0.2430 & 0.1899 & 0.3073 & 1475 & 49.7 \\
\hline & HA3 & 0.1900 & 0.0767 & 0.2230 & 0.1949 & 0.3154 & 1425 & 51.0 \\
\hline & LA3 & 0.2046 & 0.0826 & 0.1630 & 0.2100 & 0.3398 & 1365 & 55.0 \\
\hline & LA5 & 0.2095 & 0.0846 & 0.1430 & 0.2150 & 0.3479 & 1375 & 56.3 \\
\hline \multirow{4}{*}{$\begin{array}{l}\mathrm{CeO}_{2} \\
\text { series }\end{array}$} & HC5 & 0.1849 & 0.0747 & 0.1809 & 0.2524 & 0.3070 & 1375 & 55.9 \\
\hline & HC3 & 0.1899 & 0.0767 & 0.1858 & 0.2324 & 0.3153 & 1375 & 54.8 \\
\hline & LC3 & 0.2047 & 0.0827 & 0.2003 & 0.1724 & 0.3399 & 1375 & 51.2 \\
\hline & LC5 & 0.2097 & 0.0847 & 0.2051 & 0.1524 & 0.3481 & 1400 & 50.1 \\
\hline \multirow{4}{*}{$\begin{array}{l}\mathrm{Nd}_{2} \mathrm{O}_{3} \\
\text { series }\end{array}$} & HN5 & 0.1826 & 0.0737 & 0.1787 & 0.1874 & 0.3776 & 1375 & 56.5 \\
\hline & HN3 & 0.1885 & 0.0761 & 0.1844 & 0.1934 & 0.3576 & 1375 & 55.1 \\
\hline & LN3 & 0.2061 & 0.0832 & 0.2016 & 0.2115 & 0.2976 & 1375 & 50.9 \\
\hline & LN5 & 0.2120 & 0.0856 & 0.2074 & 0.2175 & 0.2776 & 1385 & 49.5 \\
\hline
\end{tabular}


Table 2. Glass composition and waste loading ranges (in mass fraction).

\begin{tabular}{lcc}
\hline Components & Min. fraction & Max. fraction \\
\hline $\mathrm{SiO}_{2}$ & 0.1473 & 0.2473 \\
$\mathrm{~B}_{2} \mathrm{O}_{3}$ & 0.0297 & 0.1297 \\
$\mathrm{Al}_{2} \mathrm{O}_{3}$ & 0.1430 & 0.2430 \\
$\mathrm{CeO}_{2}$ & 0.1524 & 0.2524 \\
$\mathrm{Nd}_{2} \mathrm{O}_{3}$ & 0.2776 & 0.3776 \\
\hline Waste loading & 0.4951 & 0.5650 \\
\hline
\end{tabular}

Table 3. Values of $c_{\max }, B_{L}$, and $T_{L}$ for Ce-borosilicate and Al-containing crystalline phases.

\begin{tabular}{lcrrrrr}
\hline & \multicolumn{3}{c}{ Ce-borosilicate } & \multicolumn{3}{c}{ Al-containing crystals } \\
\hline Glass & $c_{\max }$ & $B_{L}(\mathrm{~K})$ & $T_{L}\left({ }^{\circ} \mathrm{C}\right)$ & $c_{\max }$ & $B_{L}(\mathrm{~K})$ & $T_{L}\left({ }^{\circ} \mathrm{C}\right)$ \\
\hline L-53 & 0.372 & 15521 & 1183 & 0.217 & 10497 & 1221 \\
HA3 & 0.346 & 17217 & 1183 & 0.255 & 10417 & 1264 \\
HA5 & 0.329 & 18349 & 1184 & 0.280 & 10365 & 1292 \\
HB3 & 0.418 & 8526 & 1144 & 0.201 & 7319 & 1171 \\
HB5 & 0.449 & 3868 & 1118 & 0.191 & 5203 & 1138 \\
HC3 & 0.343 & 16541 & 1193 & 0.210 & 7346 & 1238 \\
HC5 & 0.323 & 17223 & 1200 & 0.206 & 5243 & 1250 \\
HN3 & 0.360 & 18532 & 1200 & 0.197 & 11838 & 1222 \\
HN5 & 0.352 & 20537 & 1199 & 0.183 & 12731 & 1223 \\
HS3 & 0.423 & 11861 & 1210 & 0.223 & 13397 & 1182 \\
HS5 & 0.457 & 9421 & 1167 & 0.226 & 15330 & 1155 \\
LA3 & 0.398 & 13821 & 1157 & 0.179 & 10576 & 1178 \\
LA5 & 0.415 & 12689 & 1182 & 0.154 & 10629 & 1149 \\
LB3 & 0.326 & 22499 & 1182 & 0.233 & 13667 & 1270 \\
LB5 & 0.296 & 27157 & 1222 & 0.244 & 15783 & 1303 \\
LC3 & 0.402 & 14497 & 1248 & 0.224 & 13655 & 1203 \\
LC5 & 0.422 & 13816 & 1173 & 0.229 & 15758 & 1192 \\
LN3 & 0.384 & 12517 & 1166 & 0.238 & 9159 & 1219 \\
LN5 & 0.392 & 10512 & 1167 & 0.251 & 8266 & 1218 \\
LS3 & 0.321 & 19181 & 1156 & 0.212 & 7596 & 1260 \\
LS5 & 0.287 & 21621 & 1199 & 0.208 & 5663 & 1286 \\
\hline & & & & & &
\end{tabular}


Table 4. Component coefficients for Ce-borosilicate and Al-containing crystalline phases.

\begin{tabular}{lrrrrrr}
\hline & \multicolumn{3}{c}{ Ce-borosilicate } & \multicolumn{3}{c}{ Al-containing crystals } \\
\hline & $c_{\text {max }, i j}$ & $10^{-3} B_{L, i j}(\mathrm{~K})$ & $T_{L, i j}\left({ }^{\circ} \mathrm{C}\right)$ & $c_{\text {max }, i j}$ & $10^{-3} B_{L, i j}(\mathrm{~K})$ & $T_{L, i j}\left({ }^{\circ} \mathrm{C}\right)$ \\
\hline $\mathrm{SiO}_{2}$ & 1.737 & -82.41 & 1040 & 0.364 & 88.10 & 172 \\
$\mathrm{~B}_{2} \mathrm{O}_{3}$ & 1.779 & -198.82 & 252 & -0.272 & -86.88 & -302 \\
$\mathrm{Al}_{2} \mathrm{O}_{3}$ & -0.317 & 61.19 & 1470 & 1.237 & 8.36 & 2376 \\
$\mathrm{CeO}_{2}$ & -0.415 & 42.69 & 1726 & 0.035 & -73.36 & 1684 \\
$\mathrm{Nd}_{2} \mathrm{O}_{3}$ & 0.100 & 82.93 & 1824 & -0.240 & 40.52 & 1256 \\
\hline
\end{tabular}

Table 5. Component coefficients for $\mathrm{CeO}_{2}$ crystalline phase.

\begin{tabular}{lc}
\hline Component & $\boldsymbol{c}_{\boldsymbol{i}}$ \\
\hline $\mathrm{SiO}_{2}$ & -0.084 \\
$\mathrm{~B}_{2} \mathrm{O}_{3}$ & -0.193 \\
$\mathrm{Al}_{2} \mathrm{O}_{3}$ & 0.013 \\
$\mathrm{CeO}_{2}$ & 0.183 \\
$\mathrm{Nd}_{2} \mathrm{O}_{3}$ & 0.030 \\
\hline
\end{tabular}

